\title{
MALAYSIAN UNIVERSITY STUDENTS' PERCEPTIONS AND KNOWLEDGE LEVEL OF INDUSTRIAL REVOLUTION 4.0
}

\author{
Khairunesa Isa ${ }^{1 *}$, Nurliyana Rosni ${ }^{2}$, Sarala Thulasi Palpanadan ${ }^{3}$ \\ 1,2 Department of Social Science, Universiti Tun Hussein Onn Malaysia \\ ${ }^{3}$ Department of English Language and Linguistics, Universiti Tun Hussein Onn Malaysia, \\ 1,2,3 Address: 86400, Parit Raja, Batu pahat, Johor, Malaysia \\ *Email: nesa@uthm.edu.my
}

\begin{abstract}
Nowadays, humans live in a world of industrial revolution 4.0 that leads to many changes in daily life including in the context of employment and education. In order to endure the changes that exist, various challenges have to be faced and this situation requires sufficient preparation for youngsters especially students as they are the backbone of the country's development. Thus, this study was conducted to the examine students' perceptions of industrial revolution 4.0 and the level of students' knowledge in terms of the revolution. This quantitative study using survey technique was carried out on 173 students from three clusters of Malaysian public universities which were the research university, Focus University and comprehensive university. The findings showed that student perception and level of knowledge on industrial revolution 4.0 were low. However, the respondents were found to be willing to improve their knowledge and other skills related to the Industrial Revolution 4.0 demand. The findings were hoped to motivate the academic system to enhance their strategy and approach to prepare students towards industrial revolution needs.
\end{abstract}

Keywords: Malaysian Public University, Industrial Revolution 4.0, student motivation

\section{INTRODUCTION}

The emergence of a new era of technology known as the Industrial Revolution 4.0 and the era of the Digital Economy have led the government to continue working towards the success of Malaysian Digital Policy. The advent of the Inadustrial Revolution 4.0 is an era of transformation where machines can now adapt and coordinate tasks automatically to meet human needs achieved through several systems such as Cyber Physical System (CPS), Industry 4.0, Advanced Management Program, Internet of Thing (IoT) or Internet Industry (Rifkin, 2014). The various principles on which this revolution to optimize processes productive by increasing the productivity, Big Data through greater process of sensorization, monitoring and remote control of devices, machines and processes and the application of artificial intelligence for analysis of data recorded in real time (Ustundag \& Cevikcan, 2017).

The Industrial Revolution 4.0 is the stage in information growth where the boundaries between digital, physical and biological fields are crossed (Schwab \& Samans, 2016). According to Marr (2016) in Forbes, the Industrial Revolution 4.0 is the ongoing transformation of traditional manufacturing and industrial practices combined with the latest smart technology (Marr, 2016). In brief, it is the concept of industrial automation 
where machines are extended with access to the web and connected to a network capable of seeing the entire operation and making decisions on its own. In line with the transformation, the government intends to make Malaysia a leading destination for hightech industry investment by focusing on Industry 4.0 based on the Industry 4.0 Policy Action Plan.

The technological advances have led to dramatic changes in the employment sector (Acemoglu \& Restrepo, 2020) and social life (Singh, Dhir, Das, \& Sharma, 2020). The application of information technology in the industrial revolution also allows the community to do online shopping activities (Isa \& Latiff, 2018) and the community is found to have confidence towards shop online (Khan, Rasli, Yusoff, \& Isa, 2015). This is because, the technology that emerged in IR 4.0 is able to replace the workload. Thus, human involvement is directly shrinking (A. Malik, 2019) and the issue of unemployment begins to arise. The Malaysian Employers Federation (MEF) reported that as of January 2016, almost 20,000 workers had been laid off (M. Malik, 2016). In this context, the emphasis should be given to the higher education system because university students are the backbone of the human resources who need to operate the world in the era of industry 4.0 revolution. Students in institutes of higher learning need to be equipped with certain knowledge and skills in accordance with the needs of the industry 4.0 market to ensure the marketability of graduates.

Competent, knowledgeable and highly skilled students are the main agenda of the national education system in order to contribute to a skilled workforce. According to Hamid (2018), the fourth semester students' knowledge of the Industrial Revolution 4.0 is moderate and students' readiness to go through the IR 4.0 era is also at a low level (Hamid, 2018). In addition, Ilias \& Ladin (2018) also found that the knowledge and level of readiness of students to take IR 4.0 are at a moderate level (Ilias \& Ladin, 2018). This situation is very worrying because the current market requires employers with skills in automation, digital and information technology in managing the needs of smart systems in the world of work as well as increasing productivity of the adult generation to use technology competently (Wilkesmann \& Wilkesmann, 2018) (Kayikci, 2018). Industry 4.0 is a reality that is rapidly gaining ground, marking competitive and strategic advantages among those who adopt it. The exposure of this kind of new technology for the student at higher education is a necessity so that the workforce produced through the national education system can meet the needs of the job market based on the Industrial Revolution 4.0. They have to be opened and prepared for new strategies and to understand the fact that 
risk and innovation are unavoidable. The question is whether yes or not that the students in Malaysian Public University has knowledge and readiness to adopt these innovations. Thus, this preliminary study was conducted to identify students' perceptions of industrial revolution 4.0 and identify the level of students' knowledge towards industrial revolution 4.0 .

\section{CHALLANGES IN INDUSTRIAL REVOLUTION 4.0}

Apart from providing many benefits and facilities in daily life, the existence of the Industrial Revolution 4.0 also does not miss the challenges that need to be addressed by all parties involved so that this new industrial technology transition can be optimally implemented at all levels. The lack of skilled manpower in technology and digital in line with the Industrial Revolution 4.0 is very challenging. A survey by the World Economic Forum, found that as many as 37 percent of workers in Europe do not have the basic digital skills and this will pose a big problem for them in facing and adapting the new technology revolution (Schwab, 2016).

According to $\mathrm{Xu}$ et al. (2018), the existence of the 4.0 industrial revolution can lead to high cyber-crime threats as the introduction of the Internet of Things (IoT) that integrates the physical and cyber systems will cause more vulnerabilities in network systems including hacker threats and cyber criminals (Xu et al., 2018). The findings by $\mathrm{F}$. Ahmad et al. (2020) show that the level of awareness of mobile application for education use among youth was low (F. Ahmad et al., 2020). Meanwhile, a study conducted by Kaspersky Lab (2017) also found that the number of malware samples that can attack smart devices will increase to an estimated 7000 in 2017 and possibly more in the following years (Kaspersky Lab, 2017). According to Mohamad (2020), it is estimated that from time to time about 6 billion smart devices will be used worldwide including digital clocks, televisions, smartphones, computers, laptops, air conditioning and many more (Mohamad, 2020). Thus, the low knowledge of the elements of 4.0 industrial revolution, especially among adolescents will further increase the threat of crime and cyberbullying. The implications will affect the balance of the country's development.

Job opportunities in Industry 4.0 also place great emphasis on the technical knowledge, teamwork and communication skills. This emphasis indirectly leads to changes in routine practices in organizations (A. R. Ahmad, A., Segaran, \& Sapry, 2020). The industry expects to have difficulty in getting candidates with problem-solving skills and strategic thinking, innovation, creativity, and technical knowledge. This situation in turn 
causes difficulties in organizational coordination. According to Agostini \& Filippini (2019), the rapid development of new industrial technologies will indirectly affect several levels of management in an organization or company including human resource management, production systems (processes) companies and supply chains (Agostini \& Filippini, 2019).

In the era of the industrial revolution 4.0, the education system also faces challenges that demand that the teaching and learning system to be more innovative and in line with the needs of industrial revolution 4.0. In Malaysia, the approach of industry element 4.0 in the teaching and learning system has begun to be done such as blended learning-based learning (Osman \& Hamzah, 2017), M-learning (Rase, 2013) and e-learning (Omar \& Ahmad, 2009). According to Zulkafly et al. (2011) (Zulkafly et al., 2011) and Chen (2005) (Chen, 2005) learning systems that utilize mobile technology facilities using mobile devices such as Personal Digital Assistant (PDAs), smartphones and mobile phones are more dynamic and provide access to information freely. Meanwhile, a study conducted by several educational bodies in the United States such as the American Council on Education, Huron Consulting Group and the Georgia Institute of Technology (Chen, 2005). Apparently, most educational institutions in the United States are still planning for a medium term, not long term in the implementation of industrial revolution in the system education. However, this is not enough for them to produce highly competitive and innovative graduates to meet the current market demands in the era of digital transformation 4.0 .

\section{RESEARCH METHOD}

This quantitative study was conducted by distributing the study instrument to the respondents to participate in the survey. A total of 173 students at Malaysian public universities were randomly selected as respondents from three cluster universities involving the Comprehensive University, Research University and Focus University. The definitions of the university clusters are provided in Table 1 . The questionnaire consisted three sections including Section A reffering to student demoghraphic, Section B to identify the student perception on industrial revolution 4.0 and Section $C$ to identify the level of student's knowledge towards industrial revolution 4.0. Four Likerts Scale was used in Section B and C : 1- Strongly Disagree, 2 - Disagree, 3 - Agree and 4 - Strongly Agree. The questionnaire was distributed via google form to all the respondents. The data were analysed descriptively using the Statistical Package for Social Science (SPSS) program 
version 20. The reliability test showed that the alpha value for all variables of this study was 0.765 which according to Sekaran (2009), if the reliability test value was $>0.7$, it was acceptable and reliable (Sekaran, 2009). The score means for each variable were divided into three categories which were low, moderate and high as shown in Table 2.

Table 1. The Indicator of University Clusters in Malaysia

\begin{tabular}{|c|c|c|c|}
\hline No. & Cluster of University & \multicolumn{2}{|l|}{ Indicator } \\
\hline 1 & Comprehensive University & \multicolumn{2}{|c|}{$\begin{array}{l}\text { This university provides various fields of progr } \\
\text { of postgraduates and undergraduates for the rese }\end{array}$} \\
\hline 2 & Research University & \multicolumn{2}{|c|}{$\begin{array}{l}\text { The university is responsible for active } \\
\text { experimenting with innovative methods, and ta } \\
\text { searching and developing knowledge. The adm } \\
\text { and undergraduate for the research university is }\end{array}$} \\
\hline 3 & Focus University & \multicolumn{2}{|c|}{$\begin{array}{l}\text { Focus University is an institution that pro } \\
\text { industries such as engineering, education, ma } \\
\text { admission ratio of postgraduates and unde } \\
\text { university is } 50: 50\end{array}$} \\
\hline \multicolumn{4}{|c|}{ Table 2. Score Mean Value } \\
\hline & & Score & Mean Value \\
\hline & & $1.00-2.33$ & Low \\
\hline & & $2.34-3.66$ & Middle \\
\hline & & $3.67-5.00$ & High \\
\hline
\end{tabular}

\section{RESULTS AND ANALYSIS}

\section{Section A: Respondents' Demographic}

Table 3 shows the data analysis of 173 students from three cluster universities including research university $(n=18)$, comprehensive university $(n=58)$ and focus university ( $n=97)$. The analysis showed that the majority of the respondents were females $(\mathrm{n}=115)$ and the rest were males $(\mathrm{n}=58)$.

Table 3. Respondents' Demographic

\begin{tabular}{lc}
\hline Category & Frequency (n) \\
\hline Gender & \\
Male & 58 \\
Female & 115 \\
Total & 173 \\
University Cluster & \\
Research & 18 \\
Comprehensive & 58 \\
Focus & 97 \\
Total & 173 \\
\hline
\end{tabular}

\section{Section B: Student Perception on Industrial Revolution 4.0}

Based on Table 4, the respondents' perception on Industrial Revolution 4.0 is at low level with a mean value of 1.91 . This study supported the findings of the study conducted by Tinmaz \& Lee (2019) that Korean University students are not well aware of Industry 4.0 and were skeptical of the implementations (Tinmaz \& Lee, 2019). This finding showed that eventhough majority of the respodents were from the focus university cluster, 
involving four from eleven universities under Malaysian Technical University Network (MTUN), most of them had a low perception on industrial revolution 4.0. This highlighted that the industrial revolution 4.0 was phenomenon that they had to face regardless of their interests.

Based on the student perception, the Industrial 4.0 revolution was found to reduce social problems among the community (mean $=2.37$ ). This could be due to the numerous transactions conducted by machines where social interactions had decreased. However, most of them think the industrial revolution 4.0 had more disadvantages than advantages $($ mean $=1.94)$. This could be due to the challenges that arose such as cybercrime due to the low level of awareness and knowledge of social media [16, 17], lack of employment opportunities due to the acquisition of machines and robots (A. R. Ahmad et al., 2020) and drastic transformation related to more innovative education delivery system (Osman \& Hamzah, 2017).

A. R. Ahmad et al. (2020) stated that the Industrial Revolution 4.0 would cause a change in the practice of habit in the organization which resulted in the increase in unemployment (M. Malik, 2016), but this industrial revolution era still opened employment opportunities to students, particularly in the field of related studies (mean = 1.93). It also indirectly attracted students towards the disciplines of science, technology, engineering and Mathematics (STEM) with a very low level of mean value (1.71). Supporting this findings, Tinmaz \& Lee (2019) also found that the students believed that Industrial Revolution 4.0 woul bring more job opportunities whilst some current job titles would disappear (Xu et al., 2018).

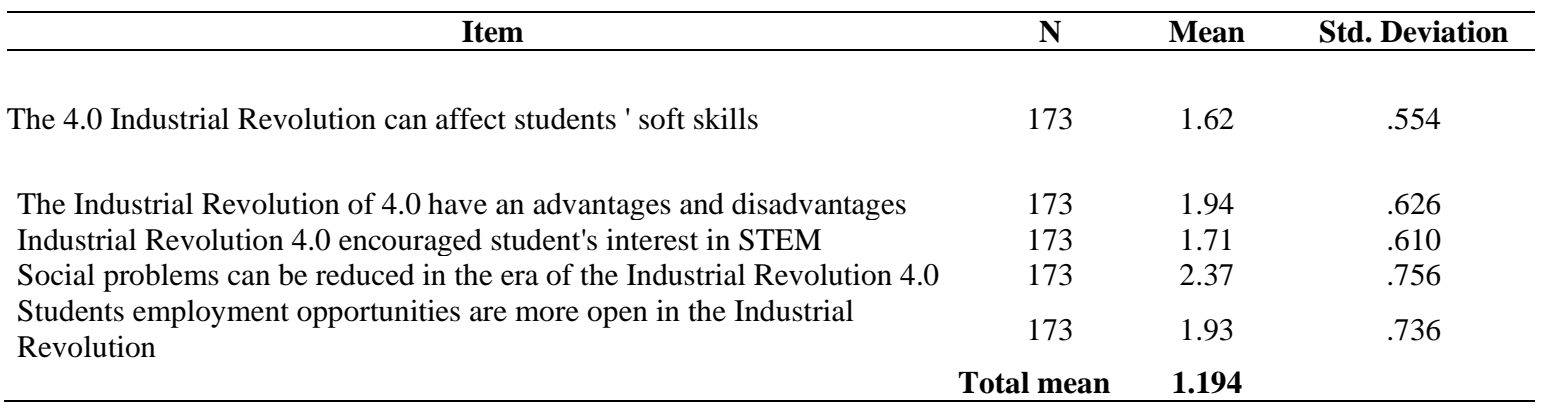

Table 5 shows a descriptive analysis on students' level of knowledge pertaining to Industrial Revolution 4.0 with the mean score 2.00. However, the respondent still knows how to using data analysis in the demand Industrial revolution $4.0($ mean $=2.30)$ and know the simulated use of technology (mean $=1.98$ ). This findings was in line with Yunos \& Din (2019) (Yunos \& Din, 2019) where their study also showed that the knowledge level 
of the Generation $\mathrm{Z}$ towards Industrial Revolution 4.0 was at low level but the respondents' readiness on the arrival of Industrial Revolution 4.0 was at high level. The same finding was obtained by the study done by Hamid (2018), in relation to student readiness on Industrial Revolution 4.0 (Hamid, 2018). Some of these findings indirectly showed the assumption that knowledge and readiness of Malaysian students on Industrial Revolution 4.0 were from low to moderate levels.

This finding showed that the respondents knew the basic matters related to industrial Revolution 4.0 such as the definitions of the Internet of Things (IoT) (mean =2.01), drone usage $($ mean $=2.08)$ and 'Grab and Waze' practice (mean =1.79). Meanwhile, realizing that many organizations were using robot in organizational management (mean $=2.14$ ), the respondents recognized that they had to expend their knowledge in information and communication technology on Industrial Revolution 4.0 (mean $=1.53$ ). According to Bucovetchi et al. (2016), students were willing to participate in blended learning as a starter to enhance their knowledge and skills (Bucovetchi et al., 2016).

Table 5. Descriptive Analysis on Student Level of Knowledge towards Industrial Revolution

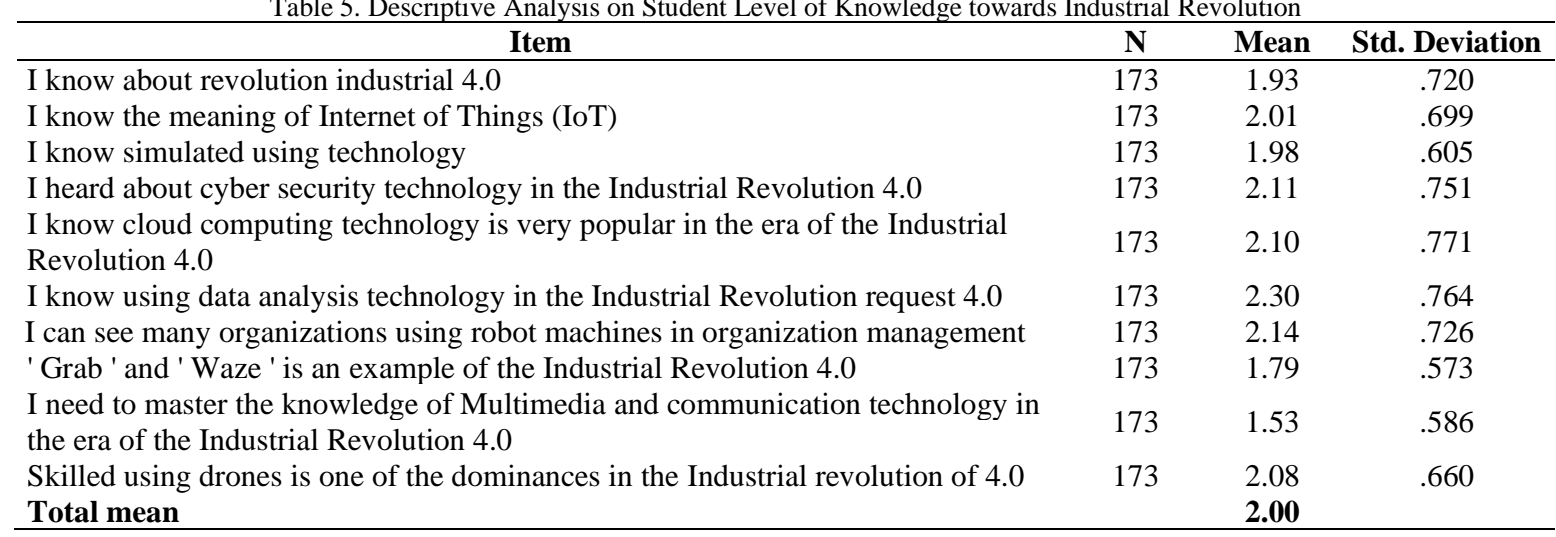

\section{CONCLUSION}

In conclusion, this finding revealed that respondents' perception and knowledge level towards the Industrial Revolution 4.0 were at a low level. It can be said that this finding showed a critical and anxious situation for Malaysia especially related to the higher education system as the students would be the future leaders who would be responsible to develop the country. Since the students were found to be ready to enhance their knowledge and skill on any related elements of Industrial Revolution 4.0, strategic planning and aggressive actions should be taken by the government and stakeholders as an effort to arouse the students' interest towards science, technology, engineering and mathematic (STEM) which are the fundamental areas of industrial revolution 4.0. 


\section{ACKNOWLEDGEMENTS}

The authors would like to thank Universiti Tun Hussein Onn Malaysia (UTHM) for supporting this research under Vot: E15501. In addition, the authors also thank the respondents for their full support for this research.

\section{REFERENCES}

Acemoglu, D., \& Restrepo, P. (2020). Robots and jobs: Evidence from US labor markets. Journal of Political Economy, 128(6), 2188-2244.

Agostini, L., \& Filippini, R. (2019). Organizational and managerial challenges in the path toward Industry 4.0. European Journal of Innovation Management.

Ahmad, A. R., A., P., Segaran, P., \& Sapry, H. R. M. (2020). Industry Revolution 4.0 and Job Creation for the University Students. International Journal, 9(3).

Ahmad, F., Hamzah, N., Wan Hassan, W. A. S., \& Mansor, A. H. (2020). “Iedutech” Mobile Application Development for Information Technology Subjects in Education among TVET Students. International Journal, 9(3).

Bucovetchi, O., Stanciu, R. D., \& Simion, C. P. (2016). Study on designing a curriculum suitable for MOOC Platforms starting out the Romanian students' expectations. Procedia Technology, 22, 1135-1141.

Chen, J. (2005). Mobile technology in educational services. Journal of Educational Multimedia and Hypermedia, 14(1), 89-107.

Hamid, N. A. (2018). Kajian Mengenai Kesediaan Pelajar Semester Empat Polimas Dalam Mengharungi Cabaran Revolusi Industri 4.0. ICompEx18 Pembentangan Kertas Penyelidikan Akademik.

Ilias, K., \& Ladin, C. A. (2018). Pengetahuan dan kesediaan Revolusi Industri 4.0 dalam kalangan pelajar Institut Pendidikan Guru Kampus Ipoh. O-JIE: Online Journal of Islamic Education, 6(2), 18-26.

Isa, K., \& Latiff, A. A. (2018). Internet Browsing Trends among Malaysians during Movement Control Order (MCO) Period. International Journal of Emerging Technologies in Engineering Research, 8(4).

Kaspersky Lab. (2017). Amount of malware targeting smart devices more than doubled in 2017. Retrieved August 10, 2020, from Kaspersky Lab website: https://www.kaspersky.com/about/press-releases/2017_amount-of-malwaretargeting-smart-devices-more-than-doubled-in-2017\#: :text=Kaspersky Lab's researchers.-, The total number of malware samples targeting smart devices has, malware targeting their connected lives.

Kayikci, Y. (2018). Sustainability impact of digitization in logistics. Procedia Manufacturing, 21, 782-789.

Khan, F., Rasli, A., Yusoff, R., \& Isa, K. (2015). Impact of Trust on Online Shopping: A Systematic Review of Literature. Journal of Advanced Review on Scientific Research, 8(1), 1-8. 
Malik, A. (2019). Creating competitive advantage through source basic capital strategic humanity in the industrial age 4.0. International Research Journal of Advanced Engineering and Science, 4(1), 209-215.

Malik, M. (2016, January). 20,000 lost their jobs in 2015, worse in 2016, says employers' group. The Malaysia Insider. Retrieved from http://www.mef.org.my/MEFITN/MInsider160105a.pdf

Marr, B. (2016). Why Everyone Must Get Ready For The 4th Industrial Revolution. Retrieved August 3, 2020, from Forbes website: https://www.forbes.com/sites/bernardmarr/2016/04/05/why-everyone-must-getready-for-4th-industrial-revolution/\#76bbd0ea3f90

Mohamad, S. (2020). Revolusi Industri 4.0: Cabaran dan Peluang. Terengganu Strategic \& Integrity Institute.

Omar, R., \& Ahmad, J. (2009). Kesedaran, Penilaian dan Penerimaan e-Pembelajaran dalam Kalangan Ahli Akademik (Awareness, Evaluation and Acceptance of eLearning Among The University's Academic Staff). Jurnal Pendidikan Malaysia (Malaysian Journal of Education), 34(1), 155-172.

Osman, N., \& Hamzah, M. I. (2017). Student readiness in learning Arabic language based on blended learning. International Journal of Applied Linguistics and English Literature, 6(5), 83-89.

Rase, R. (2013). Kesediaan pensyarah politeknik menggunakan pendekatan mpembelajaran dalam pengajaran dan pembelajaran di Negeri Johor. Universiti Tun Hussein Onn Malaysia.

Rifkin, J. (2014). The zero marginal cost society: The internet of things, the collaborative commons, and the eclipse of capitalism. St. Martin's Press.

Schwab, K. (2016). The Fourth Industrial Revolution: What It Means, How To Respond. Retrieved August 10, 2020, from World Economic Forum website: https://www.weforum.org/agenda/2016/01/the-fourth-industrial-revolution-what-itmeans-and-how-to-respond/

Schwab, K., \& Samans, R. (2016). The future of jobs: Employment, skills and workforce strategy for the fourth industrial revolution. World Economic Forum, 1-32.

Sekaran, U. (2009). Research methods for business 4th edition. Hoboken. NJ: John Wiley \& Sons.

Singh, S., Dhir, S., Das, V. M., \& Sharma, A. (2020). Bibliometric overview of the Technological Forecasting and Social Change journal: Analysis from 1970 to 2018. Technological Forecasting and Social Change, 154, 119963.

Tinmaz, H., \& Lee, J. H. (2019). A Preliminary Analysis on Korean University Students' Readiness Level for Industry 4.0 Revolution. Participatory Educational Research, 6(1), 70-83.

Ustundag, A., \& Cevikcan, E. (2017). Industry 4.0: managing the digital transformation. Springer.

Wilkesmann, M., \& Wilkesmann, U. (2018). Industry 4.0-organizing routines or innovations? VINE Journal of Information and Knowledge Management Systems. 
Xu, M., David, J. M., \& Kim, S. H. (2018). The fourth industrial revolution: opportunities and challenges. International Journal of Financial Research, 9(2), 90-95.

Yunos, S., \& Din, R. (2019). The Generation Z Readiness for Industrial Revolution 4.0. Creative Education, 10(12), 2993-3002.

Zulkafly, N. A., Koo, A.-C., Shariman, T. P. N., \& Zainuddin, M. N. (2011). Educators' perceptions towards mobile learning. Artificial Intelligence Workshop, Kuala Lumpur, Malaysia. 